\title{
Effect of solution composition on the recrystallization of kaolinite to feldspathoids in hyperalkaline conditions: limitations of pertechnetate incorporation by ion competition effects
}

\author{
Janice Littlewood ${ }^{1}$, Samuel Shaw ${ }^{2}$, Pieter Bots ${ }^{2}$, Caroline L. Peacock ${ }^{1}$, Divyesh Trivedi ${ }^{3}$ and Ian T. Burke ${ }^{1, *}$ \\ 1 Earth Surface Science Institute, School of Earth and Environment, University of Leeds, Leeds LS2 9JT, UK \\ 2 School of Earth, Atmospheric and Environmental Sciences, University of Manchester, Manchester M13 9PL, UK \\ 3 National Nuclear Laboratories, Risley, Warrington, Cheshire WA3 6AS, UK
}

[Received 29 October 2014; Accepted 6 June 2015; Associate Editor: Katherine Morris]

\section{ABSTRACT}

The incorporation of pertechnetate $\left(\mathrm{TcO}_{4}^{-}\right)$into feldspathoids produced by alkaline alteration of aluminosilicate clays may offer a potential treatment route for ${ }^{99} \mathrm{Tc}$-containing groundwater and liquors. Kaolinite was aged in $\mathrm{NaOH}$ to determine the effect of base concentration, temperature, and solution composition on mineral transformation and pertechnetate uptake. In all reactions, increased temperature and $\mathrm{NaOH}$ concentration increased the rate of kaolinite transformation to feldspathoid phases. In reactions containing only $\mathrm{NaOH}$, sodalite was the dominant alteration product; however, small amounts $(6-15 \%)$ of cancrinite also formed. In experiments containing $\mathrm{NaOH} / \mathrm{Cl}$ and $\mathrm{NaOH} / \mathrm{NO}_{3}$ mixtures, sodalite and nitrate cancrinite were crystallized $\left(\right.$ at $70^{\circ} \mathrm{C}$ ), with no reaction intermediates. The addition of $\mathrm{SO}_{4}^{2-}$ crystallized sulfatic sodalite at 40 and $50^{\circ} \mathrm{C}$, but at higher temperatures $\left(60\right.$ and $\left.70^{\circ} \mathrm{C}\right)$ sulfatic sodalite transforms to vishnevite (sulfatic cancrinite). In experiments where a pertechnetate tracer was added (at $\sim 1.5 \mu \mathrm{mol} \mathrm{1^{-1 }}$ ), only $3-5 \%$ of the ${ }^{99} \mathrm{Tc}$ was incorporated into the feldspathoid phases. This suggests that the larger pertechnetate anion was unable to compete as favourably for the internal vacancies with the smaller $\mathrm{OH}^{-}$, $\mathrm{NO}_{3}^{-}, \mathrm{SO}_{4}^{2-}$ or $\mathrm{Cl}^{-}$anions in solution, making this method likely to be unsuitable for groundwater treatment.

KEYwords: kaolinite, alkaline, alteration, pertechetate, sodalite, crancrinite.

\section{Introduction}

THERE is a global legacy of contaminated land around nuclear facilities, specifically arising from leaking storage ponds and containers (Mon et al., 2005; Perdrial et al., 2011; Wang and Um, 2012). At the Sellafield nuclear facility, UK, $\sim 20$ million $\mathrm{m}^{3}$

E-mail: i.t.burke@leeds.ac.uk

DOI: 10.1180/minmag.2015.079.6.13 of soil may be contaminated, and ${ }^{90} \mathrm{Sr},{ }^{137} \mathrm{Cs}$ and

${ }^{99} \mathrm{Tc}$ have been identified as important contaminants (Hunter, 2004). In oxic environments, technetium is highly mobile in the form of its pertechnetate anion, $\mathrm{TcO}_{4}^{-}$(Burke et al., 2005), and its half-life of $2.1 \times 10^{5}$ years (Szecsody et al., 2014) means that ${ }^{99} \mathrm{Tc}$ is particularly problematic. Hence there is a need for low cost, preferably non-invasive, techniques to be developed that might increase the pace of restoration at nuclear sites.

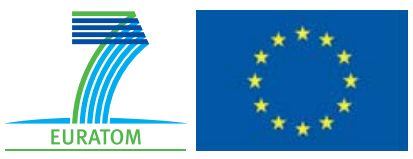

The publication of this research has been funded by the European Union's European Atomic Energy Community's (Euratom) Seventh Framework programme FP7 (2007-2013) under grant agreements $n^{\circ} 249396$, SecIGD, and $n^{\circ} 323260$, SeclGD2. 
Kaolinite $\left(\mathrm{Al}_{2} \mathrm{Si}_{2} \mathrm{O}_{5}(\mathrm{OH})_{4}\right.$, (Grim, 1968) is commonly found in sediments and soils around nuclear sites (Huertas et al., 1999), and has a simple 1:1 sheet silicate structure (Bauer et al., 1998). Under alkaline conditions, kaolinite dissolves, releasing $\mathrm{Al}^{3+}$ and $\mathrm{Si}^{4+}$ into solution, leading to the formation of secondary feldspathoid and zeolite phases (Mashal et al., 2004; Qafoku et al., 2003; Zhao et al., 2004; Wallace et al., 2013). The exact phase precipitated depends on the solution composition, base concentration, $\mathrm{Si}: \mathrm{Al}$ ratio and temperature (Deng et al., 2006b). Important features of the internal structure of these neo-formed minerals, such as cancrinite $\left(\left[(\mathrm{Ca}, \mathrm{Na})_{6}\left(\mathrm{CO}_{3}\right)_{1-1.7}\right]\left[\mathrm{Na}_{2}\left(\mathrm{H}_{2} 0\right)_{2}\right]\left[\mathrm{Si}_{6} \mathrm{Al}_{6} \mathrm{O}_{24}\right]\right)$ (Bonaccorsi and Merlino, 2005), sodalite $\left(\left(\mathrm{Na}_{8} \mathrm{Cl}_{2}\right)\right.$ [ $\left.\mathrm{Si}_{6} \mathrm{Al}_{6} \mathrm{O}_{24}\right]$ ) (Bonaccorsi and Merlino, 2005) and vishnevite $\quad\left(\left[(\mathrm{Na}, \mathrm{Ca})_{6-\mathrm{x}} \mathrm{K}_{\mathrm{x}}\left(\mathrm{SO}_{4}\right)\right]\left[\mathrm{Na}_{2}\left(\mathrm{H}_{2} \mathrm{O}\right)_{2}\right]\right.$ [ $\left.\mathrm{Si}_{6} \mathrm{Al}_{6} \mathrm{O}_{24}\right]$ ) (Bonaccorsi and Merlino, 2005), are channels and cages, which are known to selectively incorporate guest anions/cations (Deng et al., 2006b; Mon et al., 2005). Alkaline altered sediments are known to incorporate ${ }^{90} \mathrm{Sr}$ and ${ }^{137}$ Cs (Choi et al., 2005, 2006; Chorover et al., 2008; Deng et al., 2006a; Mon et al., 2005; Wallace et al., 2013); however, there is no information available regarding the successful incorporation of ${ }^{99} \mathrm{Tc}$, in the form of pertechnetate $\left(\mathrm{TcO}_{4}^{-}\right)$, into alkaline alteration products. Perrhenate $\left(\mathrm{ReO}_{4}^{-}\right)$has been incorporated into sodalite (Dickson et al., 2014; Mattigod et al., 2006) and the incorporation of this negatively charged, tetrahedral anion may support the hypothesis that $\mathrm{TcO}_{4}^{-}$could be encapsulated into similar phases. This work investigates alkaline alteration of kaolinite, particularly the effect of base concentration, temperature, and solution composition during aging, with a view to encapsulating ${ }^{99} \mathrm{Tc}$, in the form of pertechnetate $\left(\mathrm{TcO}_{4}^{-}\right)$, into a range of neoformed phases. Thus, potentially, this could provide a novel remediation treatment for land contaminated with ${ }^{99} \mathrm{Tc}$.

\section{Material and methods}

\section{Materials}

Two natural kaolinite samples were used as supplied; kaolinite from Fluka Chemicals (Switzerland) and sample K-Ga $1 \mathrm{~b}$ from the Clay Mineral Society (Chantilly, USA). Ammonium pertechnetate was obtained from LEA-CERCA (France). All other reagents (sodium hydroxide, chloride, nitrate and sulfate) were obtained from VWR international (USA).

\section{Methods}

In all instances, aerobic batch experiments were carried out in sealed $50 \mathrm{ml}$ polypropylene Oakridge tubes. Initial experiments suspended $0.4 \mathrm{~g}$ of dry kaolinite (Fluka) in $20 \mathrm{ml}$ of $\mathrm{NaOH}$ solution $(0.05 \mathrm{M}, 0.5 \mathrm{M}, 5 \mathrm{M})$, at room temperature $(R T)$ or $70^{\circ} \mathrm{C}$ in a temperature-controlled oven $(5 \mathrm{M}$ $\mathrm{NaOH}$ only). The same solid-to-solution ratio was used in all subsequent experiments. Samples were shaken on a daily basis. At intervals of 1, 7, 14 and 35 days $(R T)$, and 7 and 10 days $\left(70^{\circ} \mathrm{C}\right)$, tubes were removed from the oven. After cooling to RT, solid phases were extracted by centrifugation, at $6000 \mathrm{~g}$ for 10 minutes. The solid phase was washed four times with deionized water and dried, at room temperature, in a desiccator containing Carbosorb.

\section{Effect of solution composition and temperature}

Temperature effects were determined when $0.4 \mathrm{~g}$ dry kaolinite (Fluka) was aged in $20 \mathrm{ml} 5 \mathrm{M} \mathrm{NaOH}$ for 10 days at $40^{\circ} \mathrm{C}, 50^{\circ} \mathrm{C}$ and $60^{\circ} \mathrm{C}$. In order to investigate the effect of changing the anion composition on the alteration products formed, three additional basic $(5 \mathrm{M} \mathrm{NaOH})$ solutions were used that contained either $1 \mathrm{M} \mathrm{NaCl}, 0.5 \mathrm{M} \mathrm{NaNO}_{3}$ or $4 \mathrm{M} \mathrm{Na}_{2} \mathrm{SO}_{4}$. Kaolinite (Fluka) was aged in the $\mathrm{NaOH} / \mathrm{Cl}$ solution at $70^{\circ} \mathrm{C}$ for 10 days. Kaolinite $(\mathrm{K}-$ $\mathrm{Ga} 1 \mathrm{~b}$ ) was aged in the $\mathrm{NaOH} / \mathrm{NO}_{3}$ solution at $40^{\circ} \mathrm{C}$, $50^{\circ} \mathrm{C}$ and $60^{\circ} \mathrm{C}$ for 14 days and in the $\mathrm{NaOH} /$ $\mathrm{Na}_{2} \mathrm{SO}_{4}$ solution, at $40^{\circ} \mathrm{C}, 50^{\circ} \mathrm{C}, 60^{\circ} \mathrm{C}$ and $70^{\circ} \mathrm{C}$ for 10 days. Additionally, seven-day time series experiments were performed at $70^{\circ} \mathrm{C}$ using kaolinite $(\mathrm{K}-\mathrm{Ga}$ 1b) in $\mathrm{NaOH}$, and kaolinite (K-Ga $\mathrm{lb}$ ) in the $\mathrm{NaOH} /$ $\mathrm{Na}_{2} \mathrm{SO}_{4}$ solution, with daily sample-sacrifice.

\section{Pertechnetate sorption experiments}

Four sets of triplicate experiment were performed where ammonium pertechnetate was added at tracer concentrations $(1.5 \mu \mathrm{M})$ to each of the basic solutions described above (i.e $\mathrm{NaOH}, \mathrm{NaOH} /$ $\mathrm{SO}_{4}^{2-}, \mathrm{NaOH} / \mathrm{NO}_{3}^{-}$and $\mathrm{NaOH} / \mathrm{Cl}^{-}$) prior to the addition of kaolinite (K-Ga 1b) and incubated at $70^{\circ} \mathrm{C}$ for up to 72 days. At regular intervals, aqueous samples were separated by centrifugation and $\mathrm{Tc}$ activity determined by liquid scintillation counting on a Packard TriCarb 2100TR.

\section{Sample characterization}

The starting material and alkaline alteration end products were analysed by a number of 
complementary techniques. Powder X-ray diffraction (XRD) using a Bruker D8 diffractometer. Samples $(50-100 \mathrm{mg})$ were mounted on silicon slides and scanned between $2^{\circ}$ and $70^{\circ} 2 \theta$. Rietveld refinement was carried out using TOPAS 4.2 software (Bruker), providing quantitative analysis of the crystalline phases. (For the results presented in this study, the errors were $-1+10 \%$ at the $50 \%$ level, i.e. between $40-60 \%$ present, and $-/+1 \%$ close to the limit of detection, e.g. at the $3 \%$ level there was between $2-4 \%$ present). The $\mathrm{N}_{2}$-specific surface area was measured using the BET method, with a Micrometrics Gemini V Surface Area Analyser, with samples degassed for a minimum of 19 hours, at $R T$, with nitrogen gas prior to analysis. Electron micrographs were produced using scanning electron microscopy (SEM) coupled with energy-dispersive X-ray spectroscopy (EDS) using a FEI QUANTA 650 FEG environmental SEM. Samples were mounted on a carbon pad and coated in platinum prior to analysis.

\section{Results}

\section{Preliminary investigation of alkaline alteration of kaolinite in $\mathrm{NaOH}$ solutions}

There was no evidence of new phases in the XRD patterns (not shown) where kaolinite was aged in $0.05 \mathrm{M}$ and $0.5 \mathrm{M} \mathrm{NaOH}$ at room temperature for 35 days. A partial phase transformation to sodalite (data not shown), occurred when kaolinite was aged in $5 \mathrm{M} \mathrm{NaOH}$; however, kaolinite peaks were still dominant at day 35. XRD patterns (data not shown) for the aging of kaolinite in $5 \mathrm{M} \mathrm{NaOH}$, at $70^{\circ} \mathrm{C}$ indicated that full transformation to sodalite had occurred after 10 days. Based on these results, $5 \mathrm{M}$ $\mathrm{NaOH}$ and elevated temperatures were used in subsequent experiments.

\section{Effect of time and temperature on the alkaline alteration of kaolinite in $5 \mathrm{M} \mathrm{NaOH}$}

Kaolinite was aged over 7 days in $5 \mathrm{M} \mathrm{NaOH}$ at $70^{\circ} \mathrm{C}$. XRD patterns (Fig. 1a) show that the transformation from kaolinite to sodalite started after one day, evidenced by the sharp decrease in the main kaolinite $(\mathrm{k})$ peak intensities and the formation of peaks from the neo-formed sodalite (s) and minor amount of cancrinite (c). Rietveld analysis of the day 1 and 2 samples indicated the presence of 8 and 15 wt.\% of cancrinite (Fig. 2a), respectively. By day 3 , sodalite was the dominant phase, with only minor kaolinite peaks visible. There was no evidence of cancrinite after day 2 . Throughout the next four days, the kaolinite peaks further reduced as the sodalite peaks increased, until only minor amounts of kaolinite were visible in the XRD patterns by day 7. Rietveld analysis (Fig. $2 a$ ) of day 7 samples quantified 81 wt.\% sodalite and 19 wt.\% kaolinite. BET (Fig. 4) analysis indicates an initial increase, from 12 to $16 \mathrm{~m}^{2} / \mathrm{g}$ in the surface area at day 1 , followed by a consistent decrease in surface area up to day 6 $\left(7-10 \mathrm{~m}^{2} / \mathrm{g}\right)$.

Rietveld analysis of XRD data from 10-day experiments at lower temperatures (Fig. $6 c$ ) showed 80 wt. $\%$ sodalite and $20 \mathrm{wt} . \%$ kaolinite at $50^{\circ} \mathrm{C}$, and $24 \mathrm{wt} . \%$ sodalite, $70 \mathrm{wt} . \%$ kaolinite and $6 \mathrm{wt} . \%$ cancrinite at $40^{\circ} \mathrm{C}$. This indicates that the rate of clay transformation increased with temperature.

\section{Effect of time and temperature on the alkaline alteration of kaolinite in $5 \mathrm{M} \mathrm{NaOH}+$ $4 \mathrm{M} \mathrm{Na}_{2} \mathrm{SO}_{4}$}

The XRD patterns for kaolinite aged over 7 days, in $5 \mathrm{M} \mathrm{NaOH}$ and $4 \mathrm{M} \mathrm{Na}_{2} \mathrm{SO}_{4}$ at $70^{\circ} \mathrm{C}$ are shown in Fig. $1 b$. We note sharp decreases in the kaolinite (k) peak intensies between the starting material and the 1 day aged sample. The decrease in the kaolinite peaks, and the appearance of small peaks at $13.9^{\circ}$ and $24.4^{\circ} 2 \theta$ was consistent with the transformation from kaolinite to sulfatic sodalite/vishnevite. Rietveld analysis (Fig. $2 b$ ) of the day 1 samples quantified the neoformed feldspathoids as 2 wt.\% vishnevite and 29 wt.\% sodalite. After two days aging, the XRD patterns (Fig. 1b) showed further reductions in the kaolinite peak intensities (k) together with increasing sulfatic sodalite peak intensities (s). Rietveld analysis (Fig. 2b) for the day 2 samples showed that sulfatic sodalite had increased to $62 \mathrm{wt} . \%$, vishnevite had increased to 2.5 wt. $\%$ and kaolinite had decreased to 35.5 wt. $\%$. By day 3, peaks for vishnevite (v) increased in intensity (Fig. 1b), and only minor kaolinite peaks were visible. Throughout the next four days, the kaolinite peaks further reduced and the sodalite/ vishnevite $(\mathrm{s} / \mathrm{v})$ peaks became more prominent until only minor amounts of kaolinite were visible in the XRD patterns by day 7. After 7 days, Rietveld analysis (Fig. 2b) showed that sodalite had decreased to $24 \mathrm{wt} . \%$, vishnevite had increased to 53 wt. $\%$ and kaolinite had decreased to $23 \mathrm{wt} . \%$. This suggested that the kaolinite transformed to 

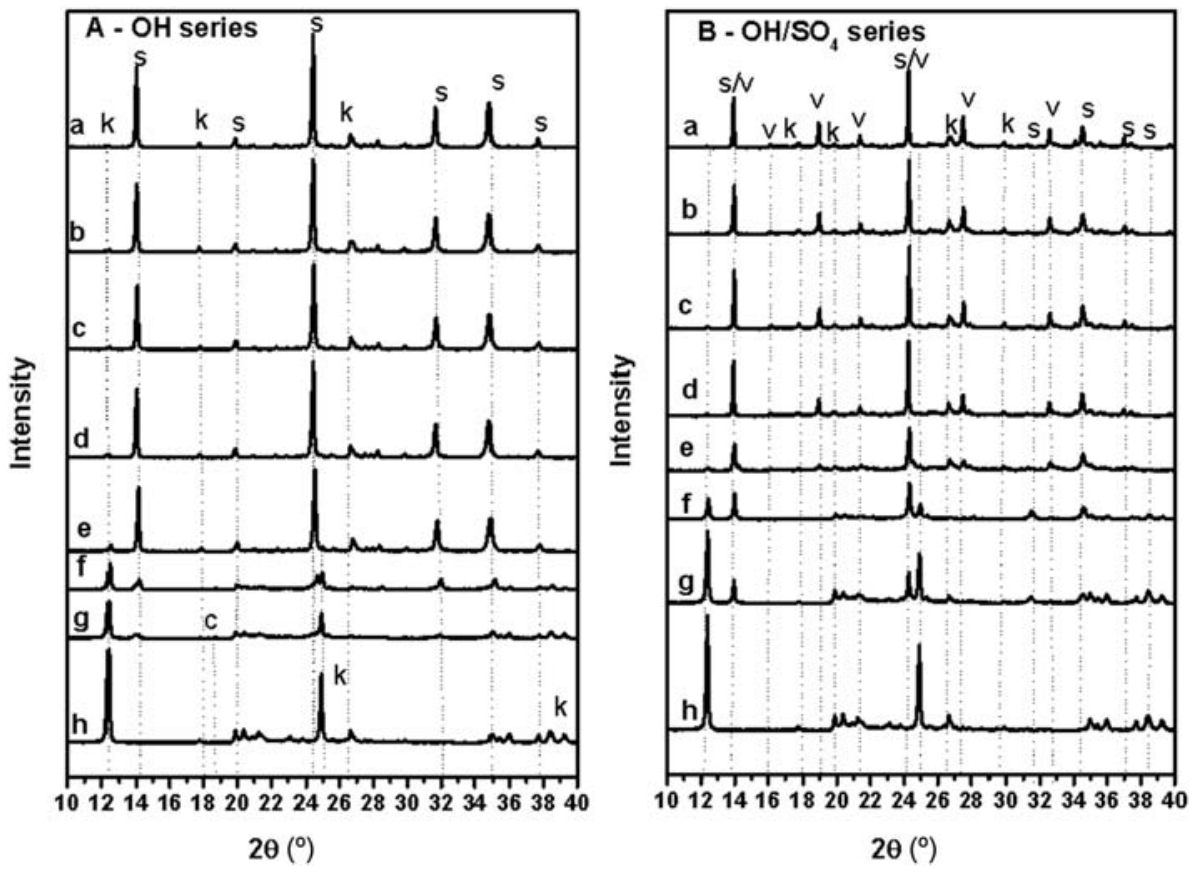

FIG. 1. X-ray diffraction (XRD) patterns of kaolinite aged in $5 \mathrm{M} \mathrm{NaOH}(\mathrm{A})$ and $5 \mathrm{M} \mathrm{NaOH} / \mathrm{SO}_{4}$ (B) at $70^{\circ} \mathrm{C}$ for $(a) 7$ days, $(b) 6$ days, $(c) 5$ days, $(d) 4$ days, $(e) 3$ days, $(f) 2$ days and $(\mathrm{g}) 1$ day. The XRD pattern of the kaolinite starting material is shown in $(h)$. Minerals are annotated as s (sodalite), $\mathrm{k}$ (kaolinite), $\mathrm{v}$ (vishnevite) and c (cancrinite).

vishnevite via a sulfatic sodalite intermediate phase. No broad humps were observed in the XRD patterns at any time during the reaction indicating that there were no amorphous phases detected at any time during the transformations.

Scanning electron microscope images (Fig. 3) of the solid phases collected during the transformation show the kaolinite starting material and the sulfatic sodalite/vishnevite alteration product at day 2 and 7. The kaolinite starting material (Fig. $3 a$ ) comprised multiple layers of stacked hexagonal plates $\sim 20-30 \mu \mathrm{m}$ in size. The EDS spectra of kaolinite showed the presence of $\mathrm{Al}, \mathrm{Si}$ and $\mathrm{O}$, with the $\mathrm{Al}$ and $\mathrm{Si}$ peaks present with equal intensities. After one day of aging, the overall crystal morphology of the kaolinite had evolved (data not shown). An interlocking desert rose morphology, characteristic of cancrinite (Deng et al., 2006c), was observed after two days (Fig. $3 b$ ). These crystallites were $\sim 2.5 \mu \mathrm{m}$ in diameter and contained $\mathrm{O}, \mathrm{Al}, \mathrm{Si}, \mathrm{Na}$, and $\mathrm{S}$ by EDS analysis, consistent with formation of sulfatic sodalite or vishnevite. By day 7 , the sample crystal morphology comprised spheres of interlocking tabular crystals (Fig. 3c) with a diameter of $\sim 3-5 \mu \mathrm{m}$. BET (Fig. 4) analysis indicates similar change to those observed in the pure $\mathrm{NaOH}$ system with an initial increase (12 to $15 \mathrm{~m}^{2} / \mathrm{g}$ ) in surface area at day 1 followed by a consistent decrease in surface area up to day 6 $\left(4-6 \mathrm{~m}^{2} / \mathrm{g}\right)$.

The XRD patterns (Fig. 5) in respect of the aging of kaolinite in $5 \mathrm{M} \mathrm{NaOH}$ and $4 \mathrm{M} \mathrm{Na}_{2} \mathrm{SO}_{4}$ at $70^{\circ} \mathrm{C}$ for 10 days, showed the presence of sulfatic sodalite and vishnevite. Rietveld analysis (Fig. 6b) of a sample aged at $60^{\circ} \mathrm{C}$ for 10 days quantified the phases to be 34 wt. $\%$ sulfatic sodalite, 8 wt.\% kaolinite and 58 wt.\% vishnevite. After 10 days aging at $50^{\circ} \mathrm{C}$ the reaction products were $69.5 \mathrm{wt} . \%$ sulfatic sodalite and $30.5 \mathrm{wt} . \%$ kaolinite. At $40^{\circ} \mathrm{C}$ the reaction products were $36 \mathrm{wt} . \%$ sulfatic sodalite and $64 \mathrm{wt} . \%$ kaolinite. This suggested that at lower temperatures kaolinite transforms to sulfatic sodalite, and to vishnevite at higher temperatures.

\section{Alkaline alteration of kaolinite in $5 \mathrm{M} \mathrm{NaOH}+$ $1 \mathrm{M} \mathrm{NaCl}$ or $0.5 \mathrm{M} \mathrm{NaNO}_{3}$}

The addition of $1 \mathrm{M} \mathrm{NaCl}$ to the $5 \mathrm{M} \mathrm{NaOH}$ solution led (Fig. 5) to the transformation of 

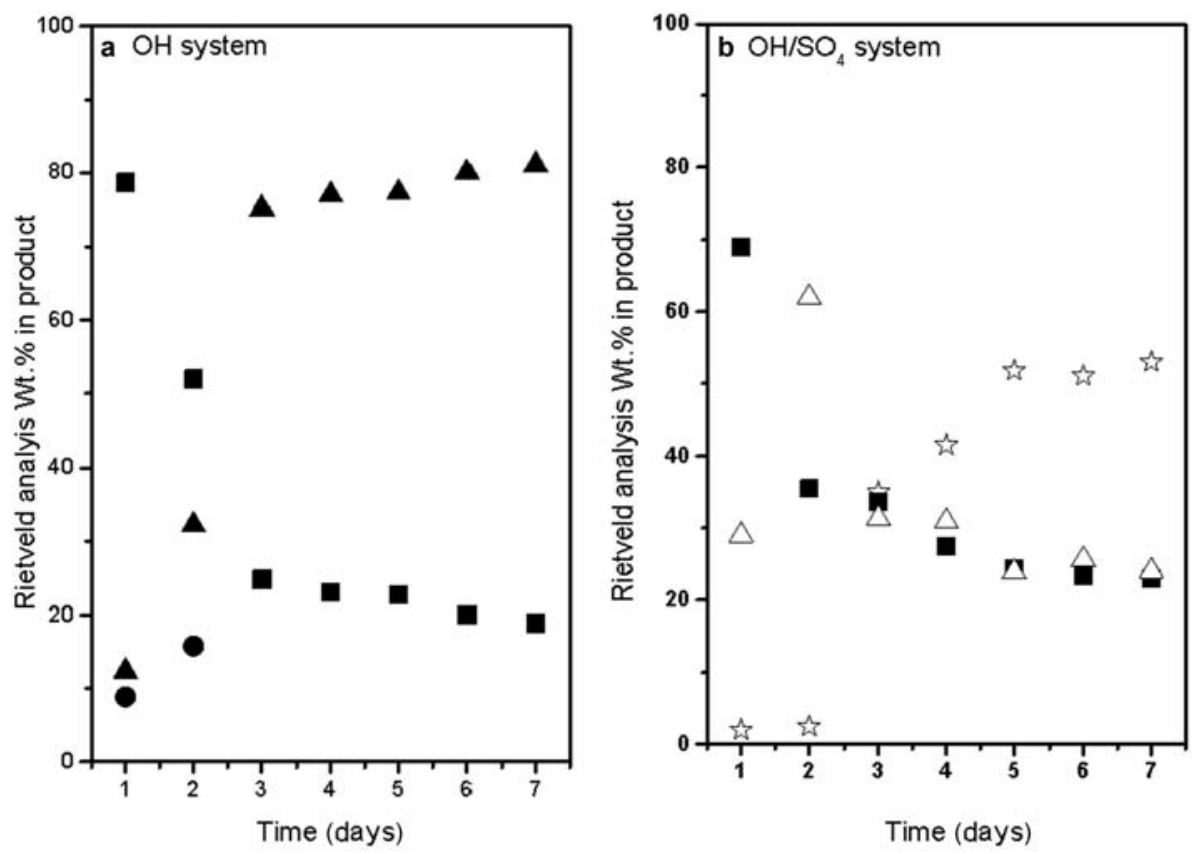

FIG. 2. Rietveld analysis for kaolinite aged in $5 \mathrm{M} \mathrm{NaOH}(a)$ and $5 \mathrm{M} \mathrm{NaOH} / \mathrm{SO}_{4}(b)$ at $70^{\circ} \mathrm{C}$ for 7 days. Mineral wt.\% are shown for kaolinite (squares), sodalite (triangles), cancrinite (circles) and vishnevite (stars). Muscovite impurity in the starting material is not shown.

kaolinite to sodalite after 10 days aging at $70^{\circ} \mathrm{C}$. In contrast XRD data show that aging kaolinite in $5 \mathrm{M}$ $\mathrm{NaOH}+0.5 \mathrm{M} \mathrm{NaNO}_{3}$ for 14 days at $60^{\circ} \mathrm{C}$ (Fig. 5) led to the formation of nitrate cancrinite. Trace amounts of kaolinite (Fig. 5) were still present after 14 days. Rietveld analysis (Fig. $6 a$ ) of the 14 day sample quantified the phases to be $98.5 \mathrm{wt} \%$ nitrate cancrinite and 1.5 wt.\% kaolinite, which suggested that the kaolinite to nitrate cancrinite transformation was almost complete after 14 days. Experiments were also carried out at lower temperatures and showed an increase in the amount of kaolinite remaining after 14 days (i.e. 8 wt. $\%$ at $50^{\circ} \mathrm{C}$ and 31 wt. $\%$ at $40^{\circ} \mathrm{C}$ ). This indicates that the rate of transformation from kaolinite to nitrate cancrinite increased as temperature increased, and no reaction intermediates were present.

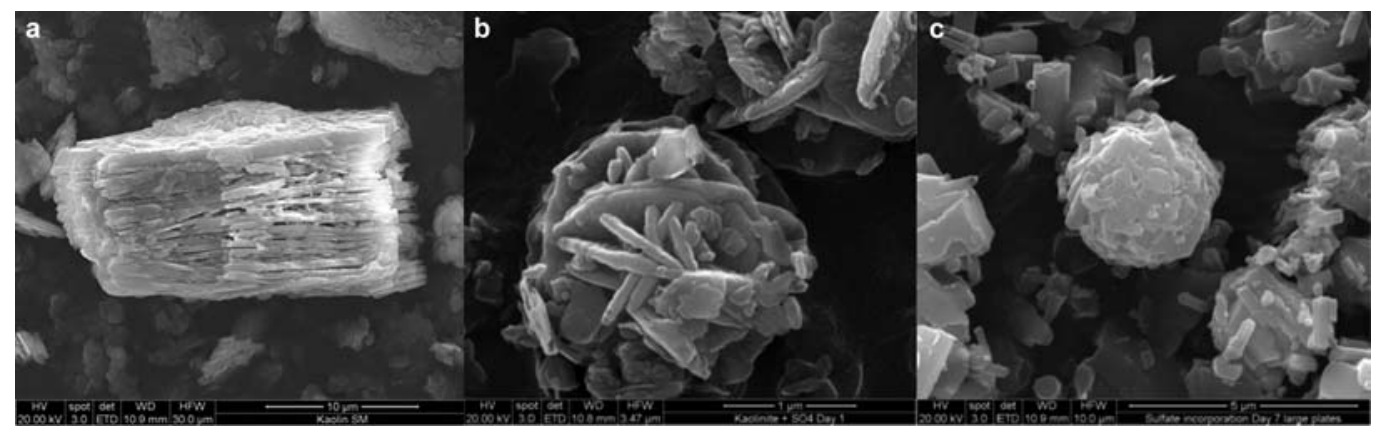

FIG. 3. SEM images for kaolinite $(a)$ and the alkaline alteration product formed during the ageing of kaolinite in $5 \mathrm{M} \mathrm{NaOH}+\mathrm{SO}_{4}(4 \mathrm{M})$ at $70^{\circ} \mathrm{C}$ for $(b) 2$ days and (c) 7 days. 


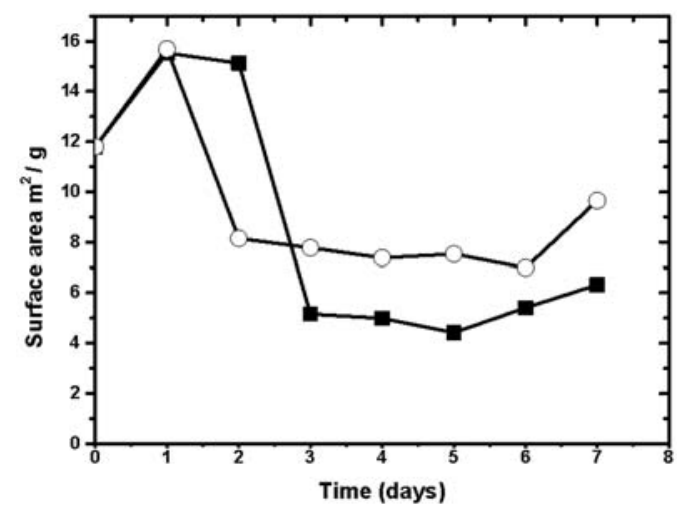

FIG. 4. Changes in mineral surface area during the reaction of kaolinite in $5 \mathrm{M} \mathrm{NaOH}$ (circles) and $\mathrm{NaOH} / \mathrm{SO}_{4}$ (squares) at $70^{\circ} \mathrm{C}$ for 7 days.

\section{Pertechnetate incorporation behaviour during phase transformation}

The $\%{ }^{99} \mathrm{Tc}$ remaining in solution (Fig. 7) during the aging of kaolinite in either $5 \mathrm{M} \mathrm{NaOH}, 5 \mathrm{M}$ $\mathrm{NaOH}+1 \mathrm{M} \mathrm{NaCl}, 5 \mathrm{M} \mathrm{NaOH}+0.5 \mathrm{M} \mathrm{NaNO}_{3}$, or $5 \mathrm{M} \mathrm{NaOH}+4 \mathrm{M} \mathrm{Na}_{2} \mathrm{SO}_{4}$, was very high, $\sim 95-97 \%$, in all instances. This suggested that only a small uptake to solids $\left(\sim 3-5 \%{ }^{99} \mathrm{Tc}\right.$; Fig. 7, inset) occurred during the first nine days of aging. Although these experiments continued for 72 days, no further uptake was observed.

\section{Discussion}

The end products which form during alkaline alteration of kaolinite vary depending on base concentration, temperature and solution composition. The lack of mineral transformation during the reaction of kaolinite in $0.05 \mathrm{M}$ and $0.5 \mathrm{M} \mathrm{NaOH}$, and partial transformation to sodalite in $5 \mathrm{M} \mathrm{NaOH}$ at $R T$, implied that there was a threshold concentration effect between $0.5 \mathrm{M}$ and $5 \mathrm{M} \mathrm{NaOH}$. Full transformation at higher $[\mathrm{NaOH}]$ is anticipated as the increased rate of a reaction is related to increases in base concentration. The rate of mineral transformation is also higher at higher temperatures (Mashal and Cetiner, 2010).

Our experiments showed that in $5 \mathrm{M} \mathrm{NaOH}$, kaolinite started to transform to sodalite at $70^{\circ} \mathrm{C}$ after one day, with only trace kaolinite remaining after 7 days. In previous work on feldspathoid precipitation from both kaolinite (Rios et al., 2009; Zhao et al., 2004) and Si-Al solutions (Deng et al.,

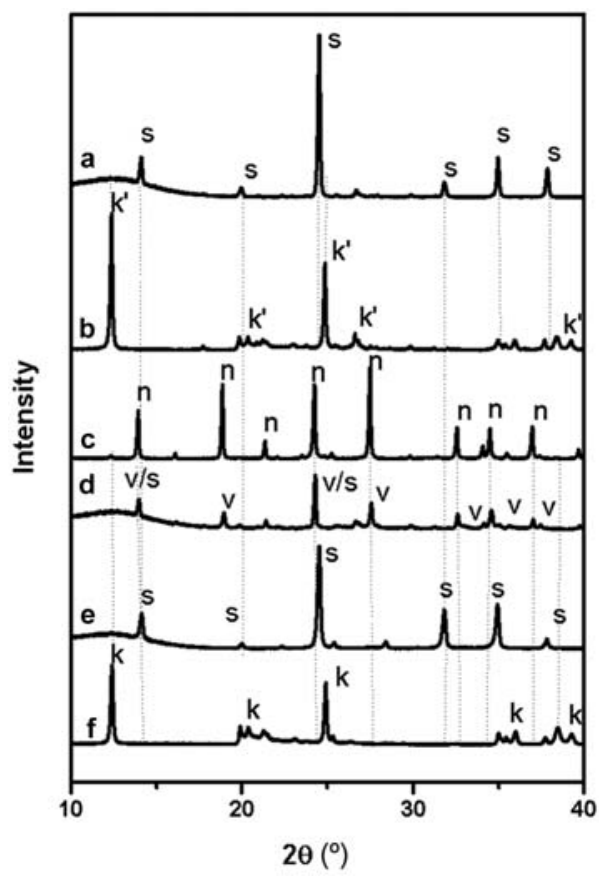

FIG. 5. XRD patterns of (a) sodalite, annotated as s, the alkaline alteration product of (b) kaolinite (Fluka), annotated as $\mathrm{k}$, aged in $5 \mathrm{M} \mathrm{NaOH}+\mathrm{Cl}$ at $70^{\circ} \mathrm{C}$ for 10 days; $(c)$ nitrate-cancrinite, annotated as $\mathrm{n}$, the alkaline alteration product of $(f)$ kaolinite (K-Ga $1 \mathrm{~b})$, annotated as $\mathrm{k}$ reacted in $5 \mathrm{M} \mathrm{NaOH}+\mathrm{NO}_{3}\left(60^{\circ} \mathrm{C}, 14\right.$ days $) ;(d)$ sulfatic sodalite/vishnevite, annotated as $\mathrm{s} / \mathrm{v}$, the alkaline alteration product of $(f)$ kaolinite (K-Ga $1 \mathrm{~b})$, annotated as $\mathrm{k}$, reacted in $5 \mathrm{M} \mathrm{NaOH}+\mathrm{SO}_{4}\left(70^{\circ} \mathrm{C}, 10\right.$ days $)$ and $(e)$ sodalite, annotated as $\mathrm{s}$, the alkaline alteration product of ( $f$ ) kaolinite $(\mathrm{K}-\mathrm{Ga} 1 \mathrm{~b})$, annotated as $\mathrm{k}$, reacted in $5 \mathrm{M}$ $\mathrm{NaOH}\left(70^{\circ} \mathrm{C}, 10\right.$ days $)$.

2006b), amorphous and zeolitic intermediates were observed before sodalite and cancrinite precipitation. However, we did not observe these intermediate phases in our experiments.

\section{Effect of solution composition on alteration product formation}

It is thought that guest anions form ion-pairs with $\mathrm{Na}^{+}$ions in solution, inducing the nucleation and growth of the neoformed feldspathoid end-products (Zhao et al., 2004). As we have stated, the end products vary depending on which anions are present in solution (Choi et al., 2006), and incorporation of guest ions is likely to be size dependent. The anion- $\mathrm{Na}^{+}$ion pairs must be able to 

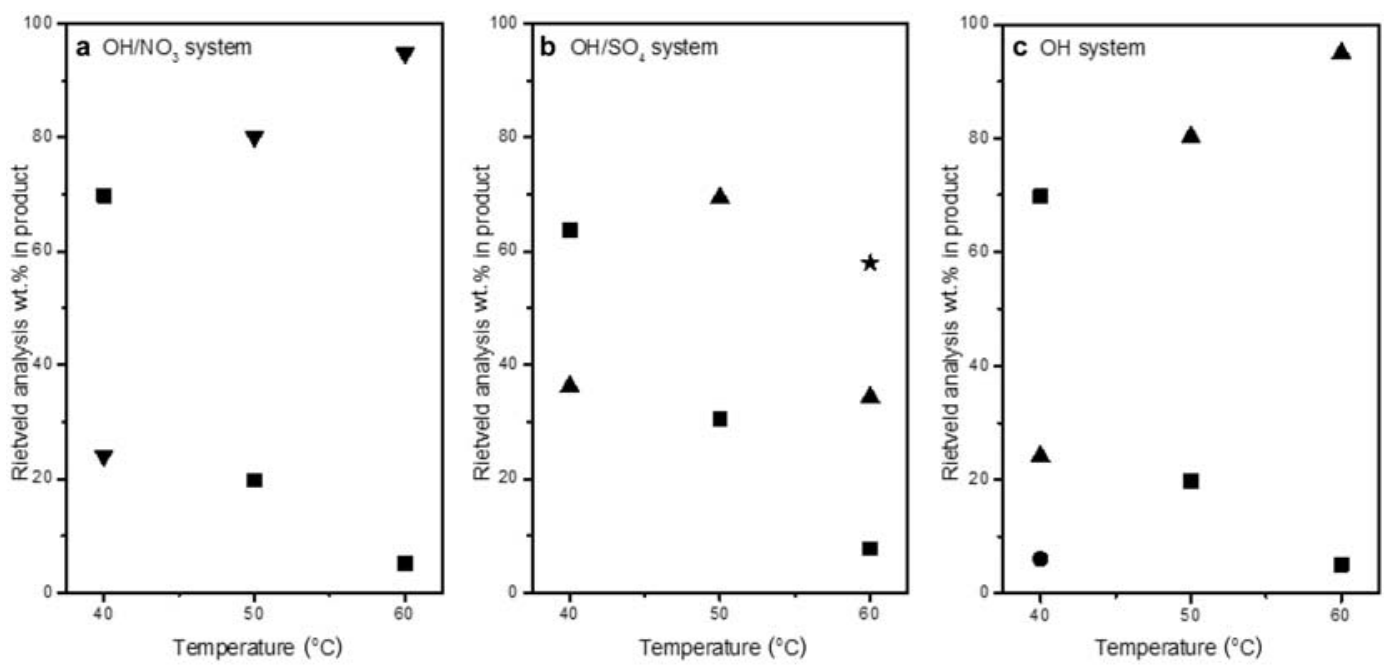

FIG. 6. Rietveld analysis for kaolinite aged in (a) $5 \mathrm{M} \mathrm{NaOH}+\mathrm{NO}_{3}$ for 14 days at 40,50 and $60^{\circ}$. Mineral wt.\% are shown for kaolinite (squares) and nitrate cancrinite (inverted triangles), in (b) $5 \mathrm{M} \mathrm{NaOH}+\mathrm{SO}_{4}$ for 10 days at 40, 50 and $60^{\circ} \mathrm{C}$. Mineral wt. $\%$ are shown for kaolinite (squares), sulfatic sodalite (triangles) and vishnevite (stars) and in (c) $5 \mathrm{M}$ $\mathrm{NaOH}$ for 10 days at 40,50 and $60^{\circ} \mathrm{C}$. Mineral wt. $\%$ are shown for kaolinite (squares), sodalite (triangles) and cancrinite (circles).

fit inside the cages and channels of the aluminosilicate minerals which grow around them (Barrer et al., 1968). In this study, the addition of sodium sulfate, sodium nitrate and sodium chloride produced end products of sulfatic sodalite/vishnevite $\left(\left[(\mathrm{Na}, \mathrm{Ca})_{6-\mathrm{x}} \mathrm{K}_{\mathrm{x}}\left(\mathrm{SO}_{4}\right)\right]\left[\mathrm{Na}_{2}\left(\mathrm{H}_{2} \mathrm{O}\right)_{2}\right]\left[\mathrm{Si}_{6} \mathrm{Al}_{6} \mathrm{O}_{24}\right]\right)$, nitrate cancrinite $\left(\mathrm{Na}_{6}\left[\mathrm{Si}_{6} \mathrm{Al}_{6} \mathrm{O}_{24}\right] \cdot 2 \mathrm{NaNO}_{3}\right)$ and sodalite $\left(\left(\mathrm{Na}_{8} \mathrm{Cl}_{2}\right)\left[\mathrm{Si}_{6} \mathrm{Al}_{6} \mathrm{O}_{24}\right]\right)$, respectively. The

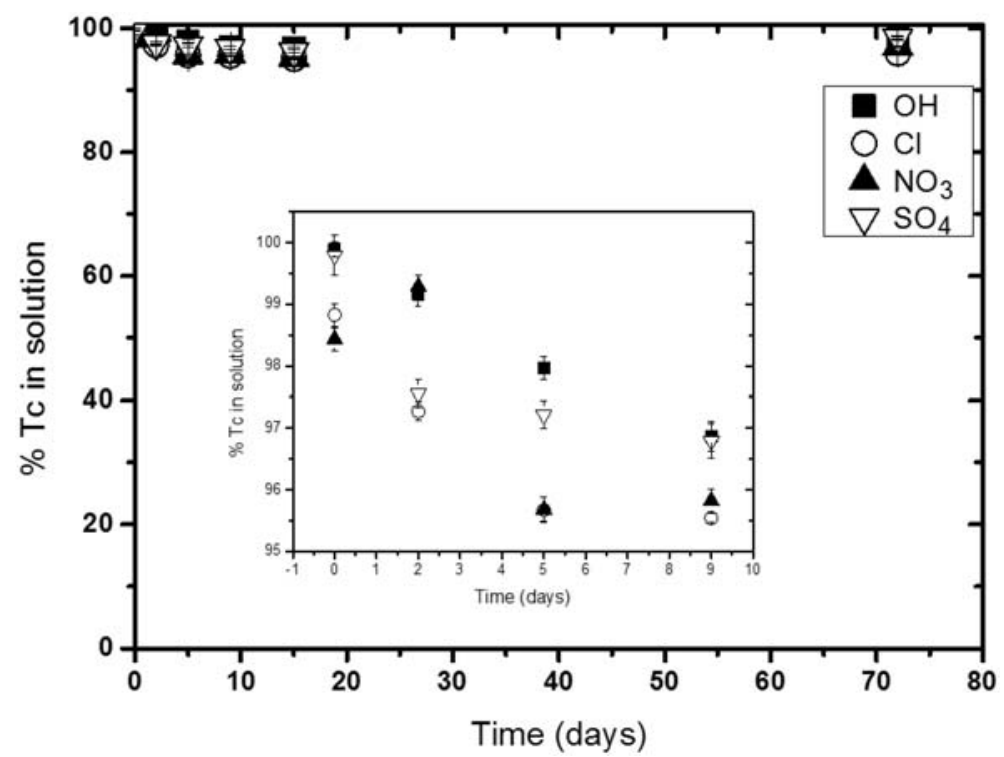

Fig. 7. $\% 99 \mathrm{Tc}(30 \mathrm{~Bq} / \mathrm{ml})$ in solution after ageing kaolinite in $5 \mathrm{M} \mathrm{NaOH}$ (squares), $5 \mathrm{M} \mathrm{NaOH}+\mathrm{Cl}$ (circles), $5 \mathrm{M}$ $\mathrm{NaOH}+\mathrm{NO}_{3}$ (triangles) and $5 \mathrm{M} \mathrm{NaOH}+\mathrm{SO}_{4}$ (inverted triangles) at $70^{\circ} \mathrm{C}$ for 72 days. 
formation of nitrate cancrinite and vishnevite resulted in guest anion substitution of $\mathrm{NO}_{3}{ }^{-}$and $\mathrm{SO}_{4}^{2-}$ into the ideal cancrinite structure. The sodalite structure does not have the wide channels found in cancrinite, only cages. These cages contain a central anion, tetrahedrally bound to four cations. As the ideal sodalite structure has a central $\mathrm{Cl}^{-}$anion, the formation of sodalite in the presence of sodium chloride is as anticipated (Barrer et al., 1974; Zhao et al., 2004).

In the $\mathrm{NaOH} / \mathrm{NO}_{3}^{-}$system no reaction intermediates were observed for the transformation of kaolinite to nitrate cancrinite (Fig. 5). The formation of nitrate cancrinite in high- $\mathrm{NO}_{3}^{-}$experiments has been previously reported (Buhl et al., 2000; Zhao et al., 2004). In our experiments, the degree of reaction for the $\mathrm{NaOH} / \mathrm{NO}_{3}^{-}$system was more than any of the other systems tested, with 69, 92 and 98 wt.\% transformation from kaolinite to nitrate cancrinite at temperatures of 40,50 and $60^{\circ} \mathrm{C}$ after 14 days.

\section{Reaction pathway for the $\mathrm{NaOH} / \mathrm{SO}_{4}^{2-}$ system}

The transformation of kaolinite aged in $\mathrm{NaOH} / \mathrm{SO}_{4}^{2-}$ has not been reported previously; therefore, this reaction pathway was studied in more detail. The XRD patterns (Fig. 1b) observed for the alteration products are similar to those for sulfate-cancrinite which was synthesized from aluminosilicate solutions (Deng et al., 2006b). The morphological changes, observed via SEM (Fig. 3), show blade-like spheres at day 2 which are similar to those which have been reported in the literature for cancrinite (Choi et al., 2005), however that reaction was performed at a lower base concentration, $(0.01 \mathrm{M}$ $\mathrm{NaOH}$ instead of $5 \mathrm{M}$ ) and for a longer time period (190 days compared to 7 days). The appearance of peaks for $\mathrm{Na}$ and for $\mathrm{S}$ in SEM-EDS analysis, which were not present in the starting material, support the formation of sulfatic sodalite/vishnevite. In summary, XRD, SEM, EDS and surface area evidence all suggest that the partial alkaline alteration of kaolinite started after 1 day of reaction.

Vishnevite (sulfate cancrinite) formation was observed after three days of reaction. Rietveld analysis (Fig. $6 b$ ) shows a gradual increase in the \% vishnevite over days 4 to 7 , to $53 \%$, with the amount of sulfatic sodalite decreasing to $24 \%$ over the same period. This is consistent with the dissolution of sulfatic sodalite and the crystallization of vishnevite. SEM images of the reaction products at day 7 (Fig. 3c) showed minor changes in morphology, in that the spheres were smaller and more tabulated, which is similar to other SEM images reported for cancrinite (Deng et al., 2006c). The smaller size of the day 7 spheres was reflected by a slight increase in the surface area, indicating some dissolution of sodalite and recrystallization to vishnevite. After seven days $78 \%$ of the original kaolinite had reacted, producing vishnevite at $70^{\circ} \mathrm{C}$ (via a sulfatic sodalite intermediate). The sodalite intermediate is more stable at lower temperatures evidenced by the lack of vishnevite at 40 and $50^{\circ} \mathrm{C}$.

\section{Proposed incorporation of ${ }^{99} \mathrm{Tc}$ into alkaline altered clays}

The potential incorporation of the technetium anion, pertechnetate $\left(\mathrm{TcO}_{4}^{-}\right)$, into cancrinite or sodalite has received some support from other authors (Mattigod et al., 2006; Dickson et al., 2014); however, the successful incorporation of technetium into feldspathoids has not yet been achieved. The results (Fig. 7) of the low-concentration pertechnetate experiments showed only a very small ${ }^{99} \mathrm{Tc}$ uptake under any of the reaction conditions studied. Up to $5 \%$ sorption of ${ }^{99} \mathrm{Tc}$ to alkaline alteration products was observed in all instances. Using sulfate to drive the reaction toward sulfate cancrinite did not produce any increased uptake over other anions such as chloride or nitrate (despite the analogous tetrahedral coordination of $\mathrm{SO}_{4}^{2-}$ and $\mathrm{TcO}_{4}^{-}$). $\mathrm{TcO}_{4}^{-}$is a relatively large anion $(\sim 2.5 \AA)$, and in cancrinite ${ }^{99} \mathrm{Tc}$ is likely to have been incorporated into a channel rather than a cage due to size constraints. Sodalite does not have channels, so the incorporation of ${ }^{99} \mathrm{Tc}$ would have been into the cages. The low ${ }^{99} \mathrm{Tc}$ uptake could suggest that the large pertechnetate anion is unable to compete favourably for the internal sites with the smaller, and therefore more size appropriate, $\mathrm{OH}^{-}, \mathrm{Cl}^{-}, \mathrm{NO}_{3}^{-}$, or $\mathrm{SO}_{4}^{2-}$ anions $(\sim 1.4, \sim 1.7, \sim 2.0$ and $\sim 2.3 \AA$ respectively), at these low concentrations. The successful incorporation of ${ }^{99} \mathrm{Tc}$ into alkaline alteration end products such as cancrinite and sodalite could provide a substantial research contribution. However, very high concentrations of pertechnetate (and conversely low concentrations of other anions) are likely to be required to produce significant uptake of

${ }^{99} \mathrm{Tc}$ into alkaline alteration end products.

\section{Conclusions}

Kaolinite undergoes alkaline alteration in the presence of $5 \mathrm{M} \mathrm{NaOH}$ (both with and without 
$\left.\mathrm{Cl}^{-}\right)$at $70^{\circ} \mathrm{C}$ to sodalite, to vishnevite if sulfate is present (via sulfatic sodalite at lower temperatures), and to nitrate cancrinite in the presence of nitrate. The rate of reaction was faster for the $\mathrm{OH}$ and $\mathrm{OH} /$ $\mathrm{NO}_{3}^{-}$systems relative to the $\mathrm{OH} / \mathrm{SO}_{4}^{2-}$ system. Up to $5 \%{ }^{99} \mathrm{Tc}$ tracer could be incorporated into these alkaline altered feldspathoids which is insufficient to consider alkaline alteration of clay minerals to be a remediation strategy for ${ }^{99} \mathrm{Tc}$.

\section{References}

Barrer, R.M., Cole, J.F. and Sticher, H. (1968) Chemistry of soil minerals. 5. Low-temperature hydrothermal transformations of kaolinite. Journal of the Chemical Society A: Inorganic, Physical, Theoretical, 2475-2485.

Barrer, R.M., Beaumont, R. and Collela, C. (1974) Chemistry of soil minerals: 14 . Action of some basic solutions on metakaolinite and kaolinite. Journal of the Chemical Society, Dalton Transactions, 934-941.

Bauer, A., Velde, B. and Berger, G. (1998) Kaolinite transformation in high molar $\mathrm{KOH}$ solutions. Applied Geochemistry, 13, 619-629.

Bonaccorsi, E. and Merlino, S. (2005) Modular microporous minerals: Cancrinte-davyne group and C-S-H Phases. Pp. 241-290 in: Micro- and Mesoporous Mineral Phases (G. Ferraris and S. Merlino, editors). Reviews in Mineralogy and Geochemistry, 57. Mineralogical Society of America and the Geochemical Society, Chantilly, Virginia, USA

Buhl, J.C., Stief, F., Fechtelkord, M., Gesing, T.M., Taphorn, U. and Taake, C. (2000) Synthesis, X-ray diffraction and MAS NMR characteristics of nitrate cancrinite $\mathrm{Na}_{7.6}\left[\mathrm{AlSiO}_{4}\right]_{6}\left(\mathrm{NO}_{3}\right)_{1.6}\left(\mathrm{H}_{2} \mathrm{O}\right)_{2}$. Journal of Alloys and Compounds, 305, 93-102.

Burke, I.T., Boothman, C., Lloyd, J.R., Mortimer, R.J.G., Livens, F.R. and Morris, K. (2005) Effects of progressive anoxia on the solubility of technetium in sediments. Environmental Science \& Technology, 39, 4109-4116.

Choi, S., Crosson, G., Mueller, K.T., Seraphin, S. and Chorover, J. (2005) Clay mineral weathering and contaminant dynamics in a caustic aqueous system II. Mineral transformation and microscale partitioning. Geochimica et Cosmochimica Acta, 69, 4437-4451.

Choi, S., O'Day, P.A., Rivera, N.A., Mueller, K.T., Vairavamurthy, M.A., Seraphin, S. and Chorover, J. (2006) Strontium speciation during reaction of kaolinite with simulated tank-waste leachate: Bulk and microfocused EXAFS analysis. Environmental Science \& Technology, 40, 2608-2614.

Chorover, J., Choi, S., Rotenberg, P., Serne, R.J., Rivera, N., Strepka, C., Thompson, A., Mueller, K.T. and
O'Day, P.A. (2008) Silicon control of strontium and cesium partitioning in hydroxide-weathered sediments. Geochimica et Cosmochimica Acta, 72, 2024-2047.

Deng, Y., Flury, M., Harsh, J.B., Felmy, A.R. and Qafoku, O. (2006a) Cancrinite and sodalite formation in the presence of cesium, potassium, magnesium, calcium and strontium in Hanford tank waste simulants. Applied Geochemistry, 21, 2049-2063.

Deng, Y., Harsh, J.B., Flury, M., Young, J.S. and Boyle, J.S. (2006b) Mineral formation during simulated leaks of Hanford waste tanks. Applied Geochemistry, 21, 1392-1409.

Deng, Y.J., Flury, M., Harsh, J.B., Felmy, A.R. and Qafoku, O. (2006c) Cancrinite and sodalite formation in the presence of cesium, potassium, magnesium, calcium and strontium in Hanford tank waste simulants. Applied Geochemistry, 21, 2049-2063.

Dickson, J.O., Harsh, J.B., Flury, M., Lukens, W.W. and Pierce, E.M. (2014) Competitive incorporation of perrhenate and nitrate into sodalite. Environmental Science \& Technology, 48, 12851-12857. DOI: $10.1021 / \mathrm{es} 503156 \mathrm{v}$.

Grim, R.E. (1968) Clay Mineralogy, $2^{\text {nd }}$ edition. McGraw-Hill Book Co., New York, 596 pp.

Huertas, F.J., Chou, 1. and Wollast, R. (1999) Mechanism of kaolinite dissolution at room temperature and pressure. Part II: Kinetic study. Geochimica et Cosmochimica Acta, 63, 3261-3275.

Hunter, J. (2004) SCLS Phase 1 - Conceptual model of contamination below ground at Sellafield. BNFL.

Mashal, K.Y. and Cetiner, Z.S. (2010) Experimental investigation of cesium mobility in the course of secondary mineral formations in Hanford sediment columns at $50^{\circ} \mathrm{C}$. Environmental Monitoring and Assessment, 169, 249-258.

Mashal, K., Harsh, J.B., Flury, M., Felmy, A.R. and Zhao, H.T. (2004) Colloid formation in Hanford sediments reacted with simulated tank waste. Environmental Science \& Technology, 38, 5750-5756.

Mattigod, S.V., McGrail, B.P., McCread, D.E., Wang, L.Q., Parker, K.E. and Young, J.S. (2006) Synthesis and structure of perrhenate sodalite. Microporous and Mesoporous Materials, 91, 139-144.

Mon, J., Deng, Y.J., Flury, M. and Harsh, J.B. (2005) Cesium incorporation and diffusion in cancrinite, sodalite, zeolite, and allophane. Microporous and Mesoporous Materials, 86, 277-286.

Perdrial, N., Rivera, N., Thompson, A., O'Day, P.A. and Chorover, J. (2011) Trace contaminant concentration affects mineral transformation and pollutant fate in hydroxide-weathered Hanford sediments. Journal of Hazardous Materials, 197, 119-127.

Qafoku, N.P., Ainsworth, C.C., Szecsody, J.E. and Qafoku, O.S. (2003) Aluminum effect on dissolution and precipitation under hyperalkaline conditions: I. 


\section{JANICE LITTLEWOOD ETAL.}

Liquid phase transformations. Journal of Environmental Quality, 32, 2354-2363.

Rios, C.A., Williams, C.D. and Fullen, M.A. (2009) Nucleation and growth history of zeolite LTA synthesized from kaolinite by two different methods. Applied Clay Science, 42, 446-454.

Szecsody, J.E., Jansik, D.P., McKinley, J.P. and Hess, N.J. (2014) Influence of alkaline co-contaminants on technetium mobility in vadose zone sediments. Journal of Environmental Radioactivity, 135, 147-160.

Wallace, S.H., Shaw, S., Morris, K., Small, J.S. and Burke, I.T. (2013) Alteration of sediments by hyperalkaline
K-rich cement leachate: Implications for strontium adsorption and incorporation. Environmental Science \& Technology, 47, 3694-3700.

Wang, G. and Um, W. (2012) Mineral dissolution and secondary precipitation on quartz sand in simulated Hanford tank solutions affecting subsurface porosity. Journal of Hydrology, 472, 159-168.

Zhao, H.T., Deng, Y.J., Harsh, J.B., Flury, M. and Boyle, J.S. (2004) Alteration of kaolinite to cancrinite and sodalite by simulated Hanford tank waste and its impact on cesium retention. Clays and Clay Minerals, 52, 1-13. 